\title{
Ethnobotanical Study of Medicinal Plants Used to Treat Human Ailments by Guji Oromo Tribes in Abaya District, Borana, Oromia, Ethiopia
}

\author{
Genene Bekele *, P. Ramachandra Reddy \\ Plant Anatomy and Taxonomy Laboratory, Department of Botany, Osmania University, Hyderabad-500007, India \\ *Corresponding Author: genucabekye@gmail.com
}

Copyright (C) 2015 Horizon Research Publishing All rights reserved.

\begin{abstract}
Medicinal plants are the integral part of the variety of cultures in Ethiopia and have been used over many centuries. Hence, the aim of this study is to document the medicinal plants in the natural vegetation and home gardens in Abaya district, Borana Zone, Oromia National Regional State, Ethiopia. Forty eight traditional healers were selected to collect data on management of medicinal plants using semi-structured interview, group discussion, and field observation. The distribution of plant species in the study areas was surveyed. Forty three plant species were documented as having medicinal value: $[21(48.8 \%)]$ were Shrubs, $[13(30.3 \%)]$ herbs, and $[9(20.9 \%)]$ trees. The root [17 (39.5\%)] was the most commonly used plant part followed by leaf $[13(30.2 \%)]$, fruits $[7(16.3 \%)]$ and stem [6 $(14.0 \%)]$. Agricultural expansion $(24.4 \%)$ in the area was found to be the main threat for medicinal plants followed by fire wood collection (18.8\%). Peoples' culture and spiritual beliefs somehow helped in the conservation of medicinal plants. Traditional healers still depend largely on naturally growing plant species and the important medicinal plants are under threat. The documented medicinal plants can serve as a basis for further studies on phytochemical and pharmacological studies.
\end{abstract}

Keywords Ethnobotany, Abaya District, Traditional Healers, Guji Oromo

\section{Introduction}

Traditional medicine is used throughout the world as it is dependent on locally available plants, which are easily accessible, and capitalizes on traditional wisdom-repository of knowledge, simple to use and affordable. These medical systems are heavily dependent on various plant species and plant based products. The current account of medicinal plants of Ethiopia, as documented for National Biodiversity Strategy and Action Plan by [18], shows that about 887 plant species were reported to be utilized in the traditional medicine. Among these, about 26 species are endemic and they are becoming increasingly rare and are at the verge of extinction. Equally threatened is the knowledge base on which the traditional medicinal system is based, as the ethnobotanical information is not documented and remains in the memory of elderly practitioners. Therefore, detailed information on the medicinal plants of Ethiopia could only be obtained when studies are undertaken in the various parts of the country where little or no botanical and ethnobotanical explorations have been made [14]. Ethnobotany tries to find out how people have traditionally used plants, for various purposes, from time immemorial [6]. Thus, ethnobotany tries to preserve valuable traditional knowledge for future generations.

The studies conducted on the traditional medicinal plants in Ethiopia are limited when compared with the multi-ethnic cultural diversity and the diverse flora of Ethiopia. Thus, this study was initiated to document the medicinal plants in the natural vegetation and home gardens in Abaya district, which assume that the data could be used as a basis for further studies on medicinal plants in Abaya district for future phytochemical and pharmacological studies.

\section{Materials and Methods}

\section{Study sites}

Abaya district is located at the northern tip of Borana zone between longitude of $37^{\circ} 40^{\prime}-38^{\circ} 40^{\prime} \mathrm{E}$ and latitudes of $6^{\circ}$ $14^{\prime}-\mathrm{N} 6^{\circ} 25^{\prime} \mathrm{N}$ and $372 \mathrm{~km}$ away from Addis Ababa to the south (Fig. 1). The district is boarded by Nations, Nationalities and Peoples of Southern Ethiopia Regional State in the north and east, Lake Abaya in the west and Gelana district in the south. The total area of the district is approximately 1871.34 sq. $\mathrm{km}$ or 187,134 hectares, and this comprise about $2.2 \%$ of the total area of the zone and the district is further divided into 26 'kebeles' (the smallest administrative unit). 


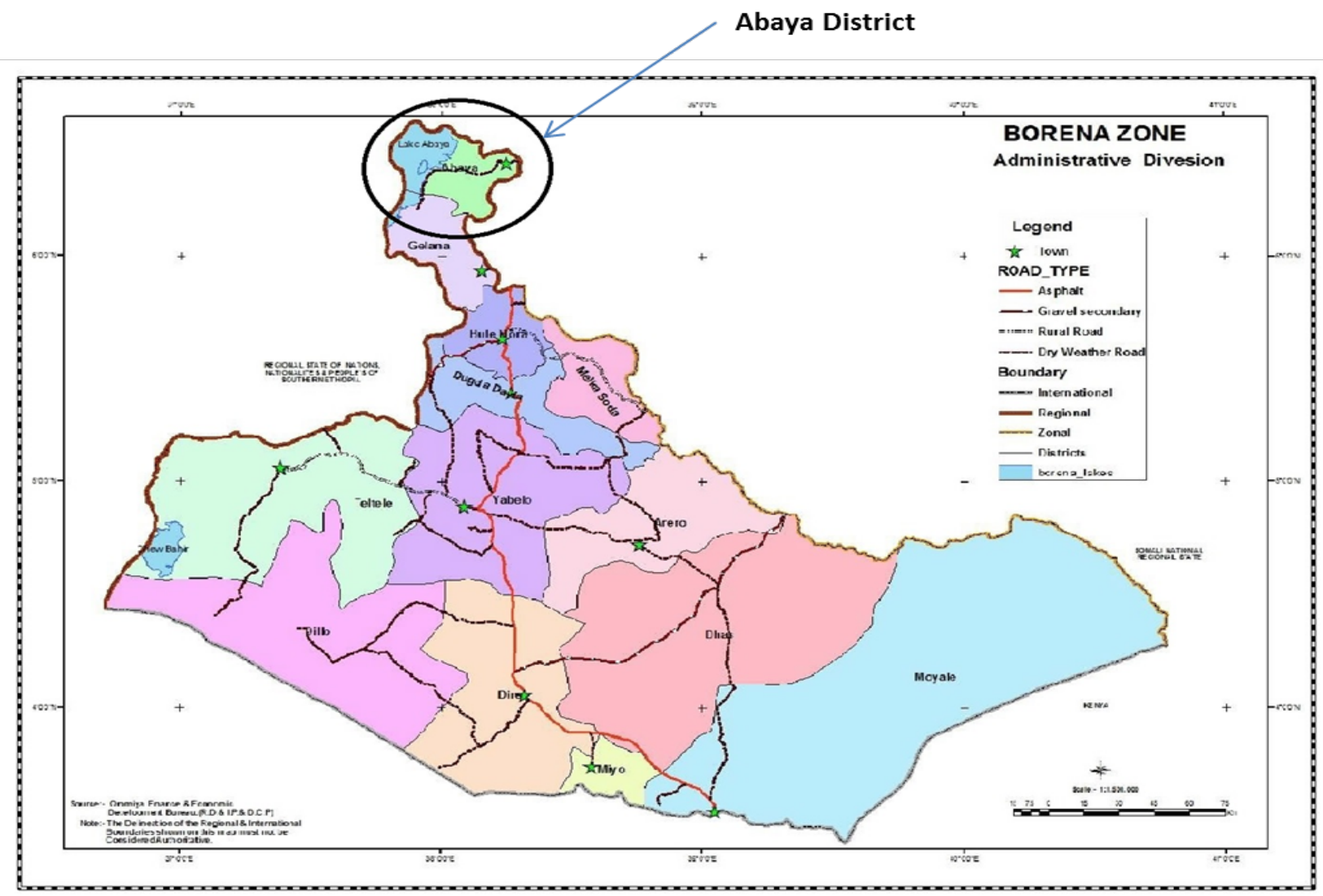

Figure 1. Location of study area in Borana Zone, Oromia Regional State

According to Central Statistical Agency administrative report (2012) Abaya district has a total population of 104,374 of which 52,547 (50.3\%) are males and 51,827 (49.7\%) are females. According to the data obtained from the District Agricultural Office, out of 187,134 hectares of the total area of the district, $45,928(24.54 \%)$ hectares are known to have potential for agriculture (cultivable land), grazing land shares 60,666 (32.42\%) hectares, forests and bush-land comprises 11,814 (6.31\%) hectares, water bodies (Abaya Lake) share $62,925(33.63 \%)$ hectares and others comprise $5,801(3.1 \%)$ hectares of land.

The rainfall distribution of the study area is bimodal (two rain seasons). The main rainy season is from June to September ('Kiremt' or 'Mahar') and the short rainy season is from February to April ('Belg'). The average annual rainfall is $107.72 \mathrm{~mm}$ and, the mean annual average temperature of the district is $20^{\circ} \mathrm{C}$. The study was conducted in twelve 'kebeles' (the smallest administrative unit) in Abaya District, Borana zone of Oromia National Regional State from April to October 2013. Prior to data collection, discussions were made with elders and local authorities to select the 'kebeles' where traditional healers were found. The 'kebeles' were selected based on availability of traditional healers, and on the recommendations of elders and local authorities in the

\section{Abaya district.}

\section{Ethnobotanical data collection}

Forty eight traditional healers (36 males and 12 females) were selected from the selected twelve 'kebeles' of the district based on the recommendation from elders and local authorities. The ages of the healers were between 25 years and 80 years. A brief group discussion was made with the informants at each 'kebele' prior to data collection to get their consent and to explain to them that their cooperation is a valuable contribution to the documentation of the traditional medicinal plants of the district. Interview, group discussion, and field observation were employed to collect data on knowledge and management of medicinal plants. The group discussions were conducted to elaborate the methods of preparation, administration and conservation of the medicinal plants. Interviews were conducted in 'Afan Oromo' language. During the study period, each informant was visited two to three times in order to confirm the reliability of the information. The responses that were not in harmony with each other were rejected. The information was collected about the plant names, methods of preparation and combination of herbal medicines, modes of administration and the ailment treated. 
Table 1. List of medicinal plants for treating human diseases in the study area, Abaya District (Habit: T-tree, Sh-shrub, H-herb, $\mathrm{Cl}$ - climber)

\begin{tabular}{|c|c|c|c|c|c|c|}
\hline Families & Scientific name & $\begin{array}{l}\text { Local name } \\
\text { 'Afan Oromo' }\end{array}$ & Habit & Preparation and application & Diseases treated & Voucher Number \\
\hline Acanthaceae & $\begin{array}{l}\text { Justicia schimperiana (Hochst.ex A. } \\
\text { Nees) T.Anders }\end{array}$ & 'Sensel' & $\mathrm{Sh}$ & $\begin{array}{l}\text { Crushed fresh/dry leaves is concocted with bark of Croton } \\
\text { macrostachyus is taken orally for three days }\end{array}$ & Intestinal parasites & GENENE B.14 \\
\hline Apiaceae & Foeniculum vulgare Mill & 'Enselal' & $\mathrm{H}$ & Crushed dry/fresh root is taken with coffee or tea as drink. & Abdominal pain & GENENE B.91 \\
\hline \multirow{2}{*}{ Araceae } & \multirow{2}{*}{ Colocasia esculenta (L.) Schott. } & \multirow{2}{*}{ ‘Godarre’ } & \multirow{2}{*}{$\mathrm{H}$} & $\begin{array}{l}\text { Crushed dry/fresh concocted with Zingiber officinale rhizome is taken } \\
\text { with coffee as drink. }\end{array}$ & Diarrhea & \multirow{2}{*}{ GENENE B.21 } \\
\hline & & & & $\begin{array}{l}\text { Fine powder of plant part mixed with water and mixture drunk or thick } \\
\text { paste applied to affected part }\end{array}$ & Trachoma & \\
\hline \multirow{3}{*}{ Asclepidaceae } & \multirow{3}{*}{ Kanahala laniflora (Forssk.) R. Br. } & \multirow{3}{*}{ 'Wundiffo' } & \multirow{3}{*}{$\mathrm{Sh}$} & $\begin{array}{l}\text { Crushed fresh/dry root concocted with roots of Croton macrostachys } \\
\text { and Senna occidentalis is taken orally }\end{array}$ & Amoebas & \multirow{3}{*}{ GENENE B.56 } \\
\hline & & & & $\begin{array}{l}\text { Crushed fresh/dry root concocted with roots of Croton macrostachys } \\
\text { and Senna occidentalis and mixed with butter is taken orally }\end{array}$ & Bronchitis & \\
\hline & & & & $\begin{array}{l}\text { Fresh/dry root powder mixed with honey is taken orally before } \\
\text { breakfast for three days. }\end{array}$ & Hepatitis & \\
\hline Asparagaceae & Asparagus africanus L. & 'Saritii' & Sh & Powder of dry root with butter is applied on wound & Wound & GENENE B.43 \\
\hline Asteraceae & $\begin{array}{l}\text { Artemisia abyssinica Sch.Bip. ex A. } \\
\text { Rich }\end{array}$ & ‘Arittii' & $\mathrm{H}$ & Crushed fresh stem with butter is applied topically & Eye infection & GENENE B.28 \\
\hline \multirow{3}{*}{ Asteraceae } & \multirow{3}{*}{ Artemisia afra Jack. ex Wild } & \multirow{3}{*}{ ‘Chikun’ } & \multirow{3}{*}{$\mathrm{H}$} & $\begin{array}{l}\text { Crushed fresh or dry leaves are boiled in water and the filtrate is taken } \\
\text { hot; orally }\end{array}$ & Abdominal pain & \multirow{3}{*}{ GENENE B.16 } \\
\hline & & & & Fresh leaves are chewed and taken orally & Headache & \\
\hline & & & & $\begin{array}{l}\text { Powdered fresh/dry leaves nixed with butter is taken with coffee } \\
\text { orally before breakfast for three days }\end{array}$ & Malaria & \\
\hline \multirow[b]{2}{*}{ Asteraceae } & \multirow[b]{2}{*}{ Carduus leptacanthus Fresen. } & \multirow[b]{2}{*}{ ‘Guccino’ } & \multirow[b]{2}{*}{$\mathrm{H}$} & Powdered dry stem mixed with butter is taken with coffee or tea. & Ascariasis & \multirow[b]{2}{*}{ GENENE B.49 } \\
\hline & & & & $\begin{array}{l}\text { Crushed dry stem concocted with Vernonia amygdalina leaves mixed } \\
\text { with water is taken orally }\end{array}$ & Haemorrhoid & \\
\hline Asteraceae & Vernonia amygdalina Del. & 'Ebicha' & Sh & $\begin{array}{l}\text { Crushed and mix with little water then drink for five days. Wash the } \\
\text { patient body with the plant part and drink for three days. }\end{array}$ & Diarrhea & GENENE B.71 \\
\hline Asteraceae & Vernonia auriculifera Hiern & ‘Rejjii’ & $\mathrm{Sh}$ & $\begin{array}{l}\text { Crushed and mix with cold water, one cup of the filtrate is given for } \\
\text { adult, one- half of the cup for children for three days }\end{array}$ & Snake poison & GENENE B.74 \\
\hline \multirow[t]{2}{*}{ Boraginaceae } & \multirow[t]{2}{*}{ Cynoglossum lanceolatum Forsk. } & \multirow[t]{2}{*}{ 'Korchibae' } & \multirow[t]{2}{*}{$\mathrm{H}$} & $\begin{array}{l}\text { Handful root is crushed by hand, small amount of cold water is added } \\
\text { to squash, the mixture is inhaled and few drops are drunk. }\end{array}$ & $\begin{array}{l}\text { Fertility \& abnormal } \\
\text { growth }\end{array}$ & \multirow[t]{2}{*}{ GENENE B..75 } \\
\hline & & & & Crushed and mix with water and drink. & Mental problems & \\
\hline Boragnaceae & Cordia africana Lam. & 'Waddesaa' & $\mathrm{T}$ & $\begin{array}{l}\text { Powdered dry root bark is sprinkled on burning charcoal and smoke is } \\
\text { inhaled covered by cloth }\end{array}$ & Evil eye & GENENE B.102 \\
\hline \multirow{4}{*}{ Brassicaceae } & \multirow{4}{*}{ Lepidium sativum $\mathrm{L}$. } & \multirow{4}{*}{ 'Feaxxo' } & \multirow{4}{*}{$\mathrm{H}$} & Dry seed powder is taken as with coffee as drink & Intestinal parasites & \multirow{4}{*}{ GENENE B.33 } \\
\hline & & & & $\begin{array}{l}\text { Crushed seeds mixed with Allium sativum bulbs and honey is taken } \\
\text { orally for five days before breakfast After each dose, one glass of } \\
\text { melted butter is recommended for immediate recovery. }\end{array}$ & Malaria & \\
\hline & & & & $\begin{array}{l}\text { Dry seed powder with crushed seed of Ocimum lamiifolium is taken } \\
\text { with coffee as drink }\end{array}$ & 'Mich' & \\
\hline & & & & $\begin{array}{l}\text { Dry seed powder with crushed seed of Ocimum lamiifolium is taken } \\
\text { with coffee as drink }\end{array}$ & Headache & \\
\hline
\end{tabular}


Table 1. List of medicinal plants for treating human diseases in the study area, Abaya District (Habit: T-tree, Sh-shrub, H-herb, Cl - climber) (Continued)

\begin{tabular}{|c|c|c|c|c|c|c|}
\hline Celastraceae & Catha edulis (Vahl.) Forssk ex Endl. & 'Jimaa' & Sh & $\begin{array}{l}\text { Crushed fresh stem concocted with leaves of Vernonia amygdalina is } \\
\text { boiled and one glass of the filtrate is taken orally }\end{array}$ & Urine retention & GENENE B.49 \\
\hline \multirow{2}{*}{ Celastraceae } & \multirow{2}{*}{ Maytenus senegalensis (Lam.) Excell } & \multirow{2}{*}{ 'kombolicha' } & \multirow{2}{*}{ Sh } & $\begin{array}{l}\text { Powdered fresh/dry seed with water or butter is taken with coffee or tea } \\
\text { as drink for five days. }\end{array}$ & Epilepsy & \multirow{2}{*}{ GENENE B.94 } \\
\hline & & & & $\begin{array}{l}\text { Powdered fresh/dry seed with Ocimum lamiifolium seed is take with } \\
\text { coffee as drink }\end{array}$ & Headache & \\
\hline Cucurbitaceae & Lagenaria siceraria (Molina) Standl. & 'Buqqe sexana' & $\mathrm{H}$ & $\begin{array}{l}\text { Ripe fruits including seeds are immersed in water for overnight; the } \\
\text { water is taken orally in the morning before breakfast. }\end{array}$ & Gonorrhoea & GENENE B.18 \\
\hline \multirow[t]{2}{*}{ Cucurbitaceae } & \multirow[t]{2}{*}{ Momordica foetida Schumach } & \multirow[t]{2}{*}{ 'Suruphaa' } & \multirow[t]{2}{*}{$\mathrm{Sh}$} & $\begin{array}{l}\text { Crushed fresh/dry root mixed with Allium sativum bulb is taken orally } \\
\text { before breakfast for three days. }\end{array}$ & Bronchitis & \multirow[t]{2}{*}{ GENENE B.23 } \\
\hline & & & & Infusion of fresh/dry root powder is taken orally & Food poison & \\
\hline Dracaenaceae & Dracaena steudneri Engl. & 'Afrafartu' & $\mathrm{T}$ & Powder of dry root is applied to wound. & Wound & GENENE B.09 \\
\hline \multirow[t]{2}{*}{ Euphorbiaceae } & \multirow[t]{2}{*}{ Croton macrostachyus Del. } & \multirow[t]{2}{*}{ 'Makkonisa' } & \multirow[t]{2}{*}{$\mathrm{T}$} & $\begin{array}{l}\text { Crushed fresh/dry leaves boiled with water is concocted with Allium } \\
\text { sativum (bulb) roasted with butter and left over night outside home is } \\
\text { taken orally at the morning }\end{array}$ & Malaria & \multirow[t]{2}{*}{$\begin{array}{l}\text { GENENE B. } \\
\quad 54\end{array}$} \\
\hline & & & & Rubbing affected part by exudates of old leaves & Ringworm & \\
\hline Euphorbiaceae & Euphorbia candelabrum Kostshy & ‘Addama’ & Sh & $\begin{array}{l}\text { Milky latex from plant mixed with roots powder of Ruta chalepensis and } \\
\text { paste applied to affected area }\end{array}$ & Ringworm & GENENE B.21 \\
\hline Euphorbiaceae & Euphorbia tirucalli $\mathrm{L}$. & ‘Anno’ & Sh & $\begin{array}{l}\text { Rubbing affected part with crushed fresh/dry root concocted with } \\
\text { crushed leaves of Coffea arabica }\end{array}$ & 'Kintarot' & GENENE B.02 \\
\hline Euphorbiaceae & Ricinus communis $\mathrm{L}$. & 'Qobbo' & Sh & $\begin{array}{l}\text { Crushed leaves with coffee, tea or milk is taken as a drunk before } \\
\text { copulation }\end{array}$ & impotency & GENENE B.06 \\
\hline Euphorbiaceae & $\begin{array}{l}\text { Tragia cinerea (Pax) Gilbert \& Radcl. } \\
\text { Smith }\end{array}$ & 'Alebelabit' & $\mathrm{H}$ & $\begin{array}{l}\text { Fine powder of plant part mixed with butter /honey and drink before } \\
\text { sexual intercourse with his partner. }\end{array}$ & 'Kintarot' & GENENE B.15 \\
\hline Fabaceae & Millettia ferruginea (Hochst.) Bark & 'Dhadhaatu' & $\mathrm{T}$ & Fresh/dry fruits powder with butter is applied topically & Skin infection & $\begin{array}{l}\text { GENENE B. } \\
28\end{array}$ \\
\hline \multirow{4}{*}{ Fabaceae } & \multirow{4}{*}{ Senna occidentalis (L.) Link } & \multirow{4}{*}{ 'Asenmeka' } & \multirow{4}{*}{$\mathrm{H}$} & Fresh root powder mixed with water is taken as a drink for three days & Bleeding nose & \multirow{4}{*}{$\begin{array}{l}\text { GENENE B. } \\
\quad 47\end{array}$} \\
\hline & & & & $\begin{array}{l}\text { Fresh root powder with butter is taken as a drink for before breakfast } \\
\text { three days }\end{array}$ & $\begin{array}{l}\text { Excessive } \\
\text { menstruation }\end{array}$ & \\
\hline & & & & Fresh root powder with honey is taken as a. drink for before copulation & Gonorrhea & \\
\hline & & & & Chewing and swallowing fresh root & Tonsillitis & \\
\hline Lamiaceae & Ocimum lamiifolium Hochst. Ex Benth. & 'Damakase’ & $\mathrm{H}$ & $\begin{array}{l}\text { Crushed fresh leaves mixed with butter is taken with coffee as drink at } \\
\text { the morning }\end{array}$ & Cough & GENENE B.07 \\
\hline Lognaceae & Buddleja polystachya Fresen & 'Hanfere' & $\mathrm{Sh}$ & Infusion of crushed dry leaves is taken orally & 'Dingetegia' & GENENE B.77 \\
\hline \multirow[b]{2}{*}{ Meliantaceae } & \multirow[b]{2}{*}{ Bersama abyssinica Fresen } & \multirow[b]{2}{*}{ 'Xibiro' } & \multirow[b]{2}{*}{ Sh } & Crushed fresh root mixed with cold water is taken orally & Bronchitis & \multirow{2}{*}{$\begin{array}{l}\text { GENENE B. } \\
\quad 87\end{array}$} \\
\hline & & & & $\begin{array}{l}\text { Crushed fresh root concocted with leaves of Ruta chalepensis with water } \\
\text { is taken orally }\end{array}$ & Febrile illness & \\
\hline Moraceae & Ficus ovata Vahl & 'Sholla' & $\mathrm{T}$ & $\begin{array}{l}\text { Powder of dry fruits mixed with butter is applied after scratching the } \\
\text { affected area }\end{array}$ & Ringworm & GENENE B.96 \\
\hline Moringaceae & Moringa stenopetala $\mathrm{L}$. & 'Sihferaw' & $\mathrm{T}$ & Chewing and swallowing fresh leaves & Vomiting & GENENE B.32 \\
\hline
\end{tabular}


Table 1. List of medicinal plants for treating human diseases in the study area, Abaya District (Habit: T-tree, Sh-shrub, H-herb, $\mathrm{Cl}-\mathrm{climber})(\mathrm{Continued})$

\begin{tabular}{|c|c|c|c|c|c|c|}
\hline \multirow{2}{*}{ Musaceae } & \multirow{2}{*}{ Ensete ventricosum (Welw.) Cheesman } & \multirow{2}{*}{ 'Warqe' } & \multirow{2}{*}{ Sh } & Crushed fresh root with water is taken orally & Abdominal pain & \multirow{2}{*}{ GENENE B. 10} \\
\hline & & & & Crushed fresh root with water is taken orally & Amoebic dysentery & \\
\hline Myrsinaceae & Embelia schimperi Vatke. & 'Hanqu' & Sh & Crushed fresh root with water is taken as a drink for several days & Leprosy & GENENE B. 83 \\
\hline Myrtaceae & Eucalyptus globules Labill & 'Barzafi adii' & $\mathrm{T}$ & Inhalation of steam of young fresh leaves with stem before bedtime & $\begin{array}{l}\text { 'Mich' (Febrile } \\
\text { illness) }\end{array}$ & GENENE B. 15 \\
\hline Phytolaceae & Phytolacca dodecandra L'Herit & 'Indoodae' & Sh & $\begin{array}{l}\text { Crushed fresh/dry leaves mixed with water is taken orally before breakfast } \\
\text { for three days. }\end{array}$ & Malaria & GENENE B.81 \\
\hline Polygonaceae & Rumex nepalensis Spreng. & 'Dangago' & $\mathrm{H}$ & Paste of fresh/dry stem powder with butter is applied topically & Wound & GENENE B.24 \\
\hline \multirow{2}{*}{ Rosaceae } & \multirow{2}{*}{ Hagenia abyssinica (Brucie.) J. F. Gmel } & \multirow{2}{*}{ 'Kosso’ } & \multirow{2}{*}{$\mathrm{T}$} & $\begin{array}{l}\text { Crushed dry fruits mix the powder with honey and a little bit of water and } \\
\text { then boil and drink before breakfast for five days. }\end{array}$ & Ascariasis & \multirow{2}{*}{ GENENE B.76 } \\
\hline & & & & $\begin{array}{l}\text { Crushed dry fruit, mix the powder with local 'tella' and leave for overnight } \\
\text { and drink before breakfast for three days }\end{array}$ & Intestinal worms & \\
\hline \multirow[b]{2}{*}{ Rosaceae } & \multirow[b]{2}{*}{ Prunus africana (Hook.F.) Kalkam } & \multirow[b]{2}{*}{ 'Sukke’ } & \multirow[b]{2}{*}{$\mathrm{T}$} & Crushed dry root bark mixed with water is taken as a drink & Ascariasis & \multirow[b]{2}{*}{ GENENE B.61 } \\
\hline & & & & $\begin{array}{l}\text { Dry root powder concocted with Parthenium hysterophorus root powder is } \\
\text { taken orally for three days. }\end{array}$ & Gonorrhoea & \\
\hline \multirow{3}{*}{ Rutaceae } & \multirow{3}{*}{ Ruta chalepensis L. } & \multirow{3}{*}{ 'Xenadami' } & \multirow{3}{*}{$\mathrm{H}$} & Crushed fresh leaves with water of or coffee is taken orally & 'Dingetega' & GENENE B.27 \\
\hline & & & & Chewing and swallowing fresh leaves & Stomach-ache & \\
\hline & & & & Chewing fresh leaves using the jaw with toothache & Toothache & \\
\hline \multirow{2}{*}{ Sapindaceae } & \multirow{2}{*}{ Dodonaea angustifolia L.F. } & \multirow{2}{*}{ 'Dhitacha' } & \multirow{2}{*}{ Sh } & Decoction of dry fruit is applied topically & Ectoparasite & \multirow{2}{*}{ GENENE B.66 } \\
\hline & & & & Powdered dry fruits mixed with water are taken orally. & Lymphatic swelling & \\
\hline Simaroubaceae & Brucea antidysenterica J.F.Mill & 'Aballo’ & Sh & Powdered fresh root bark mixed with water is applied topically & Wound & GENENE B.93 \\
\hline \multirow[t]{2}{*}{ Tiliaceae } & \multirow[t]{2}{*}{ Grewia ferruginea Hochst ex A. Rich } & \multirow[t]{2}{*}{ ‘Ogomdii' } & \multirow[t]{2}{*}{ Sh } & $\begin{array}{l}\text { Crushed fresh/dry root bark concocted with root of Ensete ventricosum and } \\
\text { mixed with water is kept overnight and taken orally as a drink before } \\
\text { breakfast. }\end{array}$ & Cough & \multirow[t]{2}{*}{ GENENE B.89 } \\
\hline & & & & $\begin{array}{l}\text { Crushed fresh/dry root bark mix with butter is taken as drink before } \\
\text { breakfast for three days. }\end{array}$ & Evil eye & \\
\hline Tiliaceae & Triumfetta tomentosa Boj. & 'Danigola' & Sh & $\begin{array}{l}\text { Mix the powder with a little bit of local 'araqi' and then apply the paste to } \\
\text { wound }\end{array}$ & Fire burn & GENENE B.73 \\
\hline Verbenaceae & Lantana camara $\mathrm{L}$. & 'Yewef kollo' & Sh & Dry stem powder mixed with water is taken orally & Diarrhoea & GENENE B.53 \\
\hline
\end{tabular}


The reported medicinal plants were collected during the field walks and trees, shrubs, herbs and climbers were listed. Voucher specimens were collected, pressed and deposited in the National Herbarium of Addis Ababa University (AAU). The plants identification was performed both in the field, and at the National Herbarium of AAU.

A descriptive statistical methods, percentage and frequency were used to analyse the data on reported medicinal plants and associated indigenous knowledge. Plant species are enumerated (Table 1) with their family name in alphabetical order, botanical names, local names ('Afan Oromo'), habits, preparations and applications, diseases treated and voucher numbers.

\section{Results and Discussion}

Most of the shrubs were collected from woodlands, rocky surfaces, secondary forests and homegardens. The herbs were mostly found in woodlands, grazing land and farmlands. The tree species were found in open woodland, farm boarders, road sides, live fences and in coffee plantation areas. Medicinal plants like Artemisia afra L., Lepidium sativum L., Enset ventricosum (Welw.) Cheesman, Ocimum lamifolia Hochst. ex Benth. and Ruta chalepensis L. were restricted to farm lands, farm boarders, live fences and home gardens. $[8,19,3]$ used similar approaches to identify sites of collection of medicinal plants.

Ethnomedicinal uses of 43 angiosperms belonging to 29 families and 40 genera have been documented. Among the total of forty three medicinal plant species investigated in this study, 18 species are mentioned in [17], 16 species in [20], 12 species in [8], and 28 species in [12]. In Africa, 12 medicinal species are documented by [2] and 16 by [9].

In terms of the number of species with medicinal properties, the families Asteraceae and Euphorbiaceae dominate each with $5(17.2 \%)$ species followed by Boraginaceae, Celastraceae, Cucurbitaceae, Fabaceae, Rosaceae and Tiliaceae each with $2(6.9 \%)$ species and the remaining 21 families each with one (3.4\%) species.

The most widely used plant remedies by the people of Abaya district were obtained from shrubs (48.8\%) followed by herbs $(30.3 \%)$. The documented data showed that the majority of medicinal plants from natural vegetation were shrubs and herbs; they were relatively common in the study area compared to tree species. This agrees with the works of $[17,8,22,12]$.

The most popular plant species in terms of demand and the number of diseases cured are Lepidium sativum L., Ruta chalapensis L., Kanahala laniflora (Forssk.)R. Br. and Artemisia afra Jack. ex Wild. Among commonly used plant parts, root $(39.5 \%)$ is the most frequently used followed by leaves $(30.2 \%)$, fruit $(16.3 \%)$ and stem $(14.0 \%)$.

The most widely sought part in the preparation of remedies was the root. The popularity of this part has serious consequences from both ecological point of view and from the sustainable survival of the medicinal plant species.
The various forms in which medicines are administered include powder $(37.2 \%)$, crushing and pounding $(51.2 \%)$, chewing (4.65\%), concoction, decoction and other each with $2.3 \%$. The mode of preparation and application vary according to disease type.

The informants' response indicated that there were variations in dosage of remedies, unit of measurement of remedies, duration and time that were prescribed for the same kind of health problems. The major factors that determine the amount to be given were age, physical fitness, stage of illness, pregnancy and presence or absence of any disease other than the disease to be treated. $[7,15,1]$ have also discussed lack of precision and standardization as a drawback of the traditional health care system.

More than 33 different diseases were recorded in Abaya district as main health problems. Out of these, malaria, diarrhoea, intestinal worms (parasites), skin diseases, gonorrhoea, etc. are the most often treated diseases with herbal medicines. The numbers of plant species used by the traditional healers for curing most often treated diseases are as follows: intestinal worms (parasites) (10), diarrhoea (3), wounds (4), haemorrhoid (3), febrile illness (4), skin diseases (4), malaria (5), gonorrhoea (3), and headache (3).

\section{Conservation and Threats of Medicinal Plants}

Some traditional practitioners had started to conserve medicinal plants by growing them in home gardens. Such as Ruta chalepensisL., Ricinus communis L., Ocimum lamiifolium, Artemisia abyssinica Sch. Bip. ex A. Rich and Artemisia afra Jack. ex Wild similar to the observation made by [10]. In most scenarios, the home gardens are fenced and protect the medicinal plants from grazing and unwise harvesting.

The main threat for medicinal plants in the natural vegetation was agricultural expansion (24.4\%). Most of the respondents perceived urbanization and construction as the least destructive factors contributing to $11.8 \%$ and $10.2 \%$ of the total score, respectively. Clearing of natural vegetation and expanding agricultural land were almost a daily activity in the study area. During the field study, it was observed that large number of big trees of Macaranga capensis (Baill.) Sim, Olea europaea L.. ssp. Cuspidate (Wall. ex G. Don), Pouteria adolfi-friederici (Engl.) Baehni and Syzygium guineense (Willd.) DC. were removed by the local people to prepare the forestlands for agricultural purpose. These factors combined with the natural vulnerability of the area may lead to further reduction in natural habitats of the medicinal plants. Pressure from agricultural expansion, wide spread cutting for fuel wood combined with seasonal drought is also reported in $[4,12,13,11,21]$ as main factor for environmental degradation.

The conservation of medical plants in the study area was limited except in Juniperous- Eucalyptus dominated 
plantation, which was the only protected natural vegetation areas. Rather, the peoples' culture and spiritual beliefs somehow had helped in the conservation of medicinal plants. For instance, the claim of the traditional healers that medicinal plants will be effective only if cut and administered by the healers or healers' relatives had helped in the conservation of the medicinal plants. Also, the collection of medicinal plants in specific season, for example, at the end of the Ethiopian calendar year in 'Pagume' (onset of September) enabled the plants to regenerate and complete their life cycle. This is true mostly for annuals, those whose leaves, fruits and seeds are used, if other destructive pressures are kept at low level.

\section{Conclusions}

Traditional medicinal plants were harvested mostly from natural vegetation area and home gardens. They were also obtained from roadsides, farmlands and live fences. The medicinal plants in the natural vegetation were under threat and to tackle these problems traditional healers had turned their face towards home gardens. However, traditional healers still depend largely on naturally growing species because of their belief that those species in the natural vegetation are more effective in the prevention and treatment of diseases and health problems. Furthermore, the documented medicinal plants can be used as a basis for further studies on the regions medicinal plants knowledge and for future studies.

\section{Acknowledgements}

We are very much grateful to local authorities, 'kebele' Farmers Association leaders and the local healers. Without whose contribution, this study would have been impossible. We would also like to thank Adde Ware Jatani Liban for her over all support and taking responsibility of family care. Finally we are grateful to National Herbarium, Addis Ababa University and Botany Department, Osmania University for allowing us using herbarium facilities and for facilitating the field research data collection.

\section{REFERENCES}

[1] Abebe, D. 1986. Traditional medicine in Ethiopia. The attempt being made to promote it for effective and better utilization. SINET: Ethiop J Sci, 9:61-69.

[2] Ankobonggo, W. 1992. The Role of African Traditional Medicine in Healthcare Delivery alongside Modern Medicine. In Plants used in African traditional medicine as practiced in Ethiopia and Uganda. Botany 2000. East and Central Africa. NAPRECA Monograph Series 2 Edited by: Edwards S, Asfaw Z. Addis Ababa: Addis Ababa University: 25-35.

[3] Awas, T. \& Asfaw, Z. 1999. Report on Ethnobotanical Study of Nations, Nationalities and People in Gambella and Benishangul Gumuz Regional States. Progress Report to Research and Publi-cation Office, Addis Ababa University.

[4] Balemie, K., Kelbessa, E. \& Asfaw Z. 2004. Indigenous Medicinal Utilization, Management and Threats in Fentale Area, Eastern Shewa, Ethiopia. Ethiop J Biol Sci, 3(1):1-7.

[5] Central Statistical Agency 2012. 2007 Population and Housing Census of Ethiopia. Adminstrative Report, Addis Ababa, April 2012.

[6] Cotton, C.M. 1996. Ethnobotany: Principles and applications. Chichester, England: John Wiley and Sons Ltd.

[7] Getahun, A. 1976. Some Common Medicinal and Poisonous Plants Used in Ethiopia Folk Medicine. Addis Ababa University.

[8] Hunde, D., Asfaw, Z. \& Kelbessa, E. 2004. Use and management of eth-noveterinary medicinal plants by indigenous people in 'Boosat', Welenchiti area. Ethiopian Journal of Biological Sciences, 3:113-132.

[9] Iwu, M.M. 1993. Handbook of African Traditional Medicinal plants. Boca Raton Ann Arbor, London: CRC Press, Inc.

[10] Kansheiae, T. 2002. Five thousand years of sustainability? A case study on Gedeo land use (Southern Ethiopia). In PhD Dissertation Wageningen: Wageningen Agricultural University.

[11] Kelbessa, E., Demissew, S., Woldu, Z. \& Edwards, S. 1992. Some threatened Endemic Plants of Ethiopia. In The Status of Some Plants in Parts of Tropical Africa, Botany 2000: NAPREC, Monograph Series No.2 Edited by: Edwards S, Asfaw Z. Ethiopia: Addis Ababa University: 35-55.

[12] Lulekal, E., Kelbessa, E., Bekele, T. \& Yineger, H. 2008. An ethnobotanical study of medicinal plants in Mana Angetu District, southeastern Ethiopia. Journal of Ethnobiology and Ethnomedicine, 4:10-34.

[13] Nanyingi, M.O., Mbaria, J.M., Lanyasunya, A.L., Wagate, C.G., Koros, K.B., Kaburia, H.F., Munenge, R.W. \& Ogara, W.O. 2008. Ethnopharmacological survey of Samburu district, Kenya. Journal of Ethnobiology and Ethnomedicine, 4:14-29.

[14] Pankhurst, R. 2001. The status and Availability of oral and written knowledge on traditional health care in Ethiopia. In Proceedings of the National Workshop on Biodiversity Conservation and Sustainable Use of Medicinal Plants in Ethiopia Addis Ababa: IBCR; 92-106.

[15] Sofowara, A. 1982. Medicinal Plants and Traditional Medicine in Africa New York: John Wiley and Sons, Ltd.

[16] Taddesse, M. 1986. Some Medicinal Plants of Central Shewa and Southwestern Ethiopia. SINET Ethiop J Sci, 9:143-167.

[17] Tamene, B. 2000. A Floristic Analysis and Ethnobotanical Study of the Semi-Wet land of Cheffa Area, South Wello, Ethiopia. In M.Sc. Thesis Addis Ababa University.

[18] Tesema, T., Mirutse, G. \& Nugusu A. 2002. National Biodiversity Strategy and Action Plan (BSAP) Project: Resource Base of Medicinal Plants of Ethiopia. Institute of Biodiversity Conservation, Addis Ababa.

[19] Tolossa, E. 2007. Use, Treat and Conservation of Traditional Medicinal Pants by Indigenous People in Gmbi District 
in Abaya District, Borana, Oromia, Ethiopia

Western Wellega, West Ethiopia. In M.Sc. Thesis Addis Ababa University.

[20] Wondimu. T., Asfaw, Z. \& Kelbessa, E. 2007: Ethnobotanical study of medicinal plants around 'Dheeraa' town, Arsi Zone, Ethiopia. Journal of Ethnopharmacology, 112:152-161.

[21] Yineger, H., Yewhalaw, D. \& Teketay, D. 2008.
Ethnomedicinal plant knowledge and practice of the Oromo ethnic group in southwestern Ethiopia. Journal of Ethnobiology and Ethnomedicine, 4:11-28.

[22] Yineger, H. \& Yewhalaw, D. 2007. Traditional medicinal plant knowledge and use by local healers in Sekoru District, Jimma Zone, Southwestern Ethiopia. Journal of Ethnobiology and Ethnomedicine, 3:24-39. 